\title{
USGS Investigations of Water Produced During Hydrocarbon Reservoir Development
}

\section{Introduction}

Significant quantities of water are present in hydrocarbon reservoirs. When brought to the land surface during oil, gas, and coalbed methane production, the water-either naturally occurring or injected as a method to enhance production - is termed produced water. (See sidebar, Definitions of selected terms, next page.) Produced water is currently managed through processes such as recycling, treatment and discharge, spreading on roads, evaporation or infiltration, and deep well injection. U.S. Geological Survey (USGS) scientists conduct research and publish data related to produced water, thus providing information and insight to scientists, decisionmakers, the energy industry, and the public. The information advances scientific knowledge, informs resource management decisions, and facilitates environmental protection. This fact sheet discusses integrated research being conducted by USGS scientists supported by programs in the Energy and Minerals and Environmental Health Mission Areas. The research products help inform decisions pertaining to understanding the nature and management of produced water in the United States.

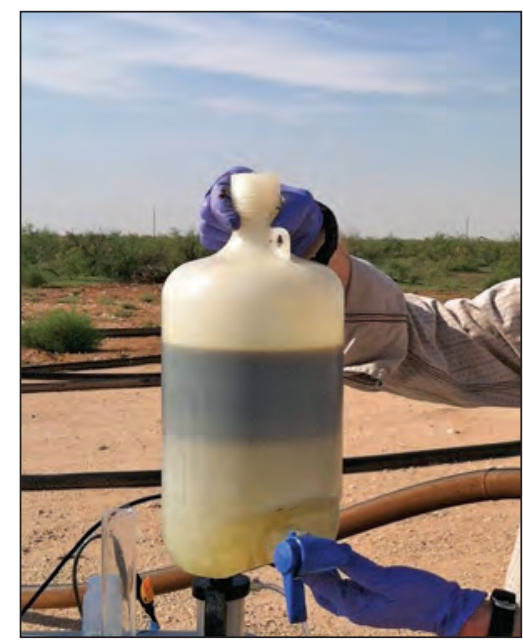

\begin{abstract}
A layer of oil (top) and produced water (bottom) separating from one another after being collected from an oil well in the Permian Basin, Texas. Photograph by Francisco Reyes, USGS.
\end{abstract}

In conventional oil and gas wells, produced water generally consists of naturally occurring brine present in the reservoir and water injected nearby to push the hydrocarbon deposit into production wells (water flooding). Alternatively, for continuous or unconventional resources, such as shale gas or tight oil, fracturing fluid and a solid material (proppant) are injected into the reservoir under very high pressure in order to create fractures to increase rock porosity and permeability. In this scenario the produced water is usually a mixture of the injected fluids with formation brines in the reservoir. The quality of produced water is variable, ranging in salinity from similar to that of drinking water to several times more saline than sea water. Various constituents can be contained in produced water from petroleum or coal reservoirs, including dissolved salt, petroleum and other organic compounds, suspended solids, trace elements, bacteria, naturally occurring radioactive materials (NORM), and anything injected into the well (Clark and Veil, 2009). Because of the considerable variability in water chemistry and the potentially large volumes involved, the management of produced water is an important and complex issue.

Using 2007 data, Clark and Veil (2009) estimated that hydrocarbon production in the United States generated 57.4 million barrels of water per day ( 1 barrel $(\mathrm{bbl})=42$ gallons). Since then, a rapid increase in hydrocarbon production across the United States, particularly for shale gas, tight gas, tight oil, and coalbed methane, has led to a commensurate increase in produced water volumes. In Pennsylvania, for example, natural gas production increased from 0.20 trillion cubic feet in 2006 to 2.26 trillion cubic feet in 2012, primarily due to the production of natural gas from the Marcellus Shale (Pennsylvania Department of Environmental Protection, 2013). During this same period, the annual amount of produced water in Pennsylvania increased from 6.6 million bbl to 24.4 million bbl. The Bakken reservoir in the Williston Basin in Montana, North Dakota, South Dakota, and Saskatchewan is another area of recent and dramatic increased hydrocarbon production (graph) wherein management plans for produced water are being developed. The dramatic increase in hydrocarbon reservoir development and the corresponding rise in the volume of associated produced water has taken place in areas of the United States that have not previously seen such intense development. The rapid expansion of energy resource extraction has the potential to overwhelm local infrastructure and strain many parts of the produced water cycle, including the storage, treatment, reuse, transportation, or disposal of these waters.

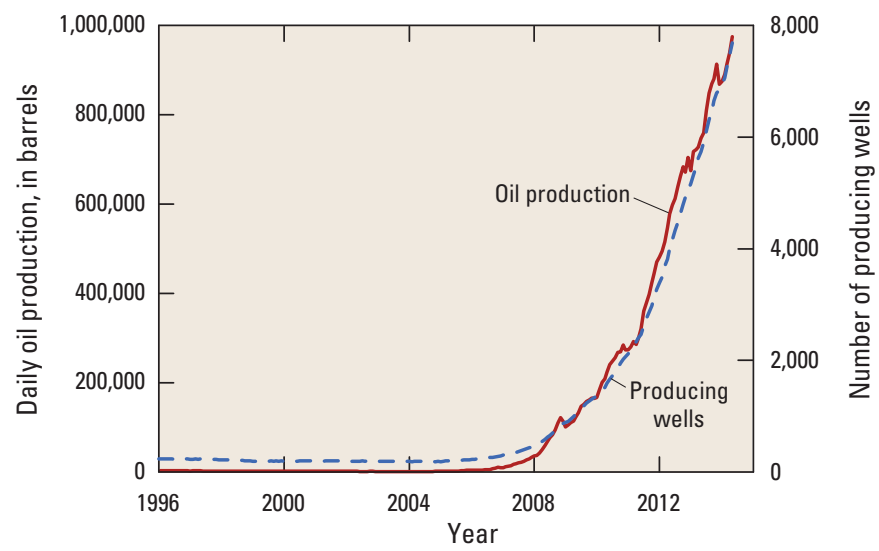

Oil production from the Bakken Formation showing the increase in the number of producing wells. Data provided by Department of Natural Resources, North Dakota Industrial Commission. 


\section{Definitions of selected terms}

flowback water During the development of unconventional resources such as shale gas or tight oil, a fracturing fluid and a proppant are injected into the reservoir under high pressure in order to create fractures to increase rock porosity and permeability. Flowback water consists primarily of the injected water and is generated in the first few days to weeks following hydraulic fracturing.

formation brine or water Naturally occurring water, typically of brackish to brine salinity, which is present in oil and gas reservoirs. Formation water in many coalbed methane reservoirs is relatively fresh.

produced water Any water produced from a hydrocarbon well, including flowback water, formation water, injected fluids, water condensing from the gas phase, and mixtures thereof (also referred to as co-produced water).

conventional hydrocarbon resource A relatively high permeability oil and (or) gas accumulation with a distinct waterhydrocarbon boundary.

unconventional hydrocarbon resource A continuous hydrocarbon accumulation, typically in a low permeability reservoir, which lacks a distinct hydrocarbon-water contact and often covers a substantial area. Examples include shale gas, tight gas, tight oil, and coalbed methane reservoirs.

\section{Management of Produced Water}

Nationally, more than 95 percent of produced water from hydrocarbon resource development is disposed of by injection, either into special (Class II: Associated with oil and gas production) underground injection control wells or into petroleum wells to enhance recovery or to maintain reservoir pressure (Clark and Veil, 2009). The proportionally small remainder that is not injected is either treated and disposed of in the surface environment, beneficially utilized, or recycled for use in hydraulic fracturing or other oil and gas operations. Lower salinity and better quality co-produced waters, which are often treated in some way, have many uses, including for irrigation, water for livestock, ecosystem and habitat maintenance, and aquaculture. Other known uses include road spreading for dust control and deicing, fire control, water for drilling mud, and water for cooling or other processes in electrical power generation and other industrial activities. While safeguards are typically included in environmental regulations, unintended consequences (both positive and negative) can result from the beneficial uses of produced water.

\section{Beneficial Uses of Produced Water}

The water and salt that make up brine in sedimentary basin formations have been of interest to the oil and gas industry for more than 100 years. In some areas of the country, salts and other constituents in the brine historically have been, and in some cases currently are, of significant economic value. For instance, iodide recovered from produced water in Oklahoma is the largest source of iodine in the United States (Polyak, 2013). Produced water can be treated and recycled, particularly in arid environments, for agricultural uses in crop production and livestock management. Increasingly, produced water is used to enhance the production of hydrocarbons; waterflooding and hydraulic fracturing are used in the development of unconventional resources.

\section{Potential Environmental Concerns}

The infrastructure used to store and transport produced water can fail, resulting in spills, leaks, and other environmental releases. Legacy oil and gas operations, including improperly abandoned or poorly cemented wells, could potentially serve as conduits for deep subsurface fluids to move into shallow freshwater systems. Disposal procedures (primarily historical) for produced water in evaporation pits can impact shallow groundwater. The deep injection of produced water can produce earthquakes, and the water can affect shallow water by migrating through improperly abandoned wells.

The first USGS multidisciplinary investigation to study the impacts of produced water was conducted from 2001 to 2006 at Skiatook Lake in the southeastern part of the Osage Indian Reservation in northeastern Oklahoma. The study focused on determining the fate of produced water and the effects of produced water disposal on the near-surface environment (Herkelrath and others, 2007; Kharaka and others, 2007). Results from the investigation (http://toxics.usgs.gov/sites/produced_water/) helped provide information that environmental officials, land managers, petroleum companies, and land owners need to assess human and ecosystem impacts and to develop risk-based corrective actions to clean up contamination from produced water.

\section{Mapping Brine Contamination and Geochemical Fingerprinting}

Borehole, ground, and airborne geophysical survey methods have been used by the USGS to characterize and map the nearsurface and subsurface distribution of produced water and its hydrogeologic setting. USGS studies have examined the radionuclide content of produced water and have used geophysical methods to map surface radiometric variations. Additional studies mapped electrical property variations because the electrical conductivity of water increases in direct proportion to increases in total dissolved solids. Airborne electromagnetic (AEM) surveys were first used to map the contamination of shallow groundwater (less than 300 feet below ground surface) resulting from the disposal of salineproduced water at oil fields. Research at the East Poplar oil field in northeastern Montana (Thamke and Smith, 2014) has related the variations in subsurface electrical conductivity, interpreted from an AEM survey, to groundwater models, improving the ability to predict the movement of a hidden, underground saline water plume, several miles in aerial extent, caused by the failure of an injection well.

Geochemical tools, such as chemically fingerprinting produced water from specific reservoirs, help identify potential sources of contaminants in the surface environment (such as chloride in soil, groundwater, and lakes). Produced water frequently exhibits characteristic ratios of sodium to bromine and chlorine to bromine, which are useful in determining the primary source of their salinity. USGS scientists have used this method to determine the source of salts in produced water from the Marcellus Shale gas wells in Pennsylvania (Engle and Rowan, 2014). Isotopes (molecules with the same number of protons but different numbers of neutrons; for 
instance, oxygen-18 versus oxygen-16) are another important tool that has been used to differentiate water from different reservoirs. Using ratios of strontium-87 (radiogenic) to strontium-86 (stable) and radium-228 to radium-226 (both radiogenic), USGS scientists are able to distinguish otherwise nearly identical water produced from different reservoirs (Rowan and others, 2011).

\section{Characterization}

Information on water quality and physical parameters provides context for potential environmental impacts, as well as providing industry with base-level information about use. One source of such data is the USGS Produced Waters Geochemical Database (Blondes and others, 2014), which provides data for more than 160,000 produced water samples, including samples from shale gas, tight oil, and coalbed methane wells. A broad array of information, such as the potential mineral value, viability of disposal options, potential for mineral scale, and possible environmental risks can be gleaned from such basic data. For instance, data in table 1 indicate substantial differences in produced water composition from a coalbed methane well in Wyoming, a conventional oil well in Ohio, and a shale gas well in Pennsylvania. Despite this new dataset, important data gaps still exist. To address this issue, the USGS continues to actively characterize produced water samples in areas of critical need, including the Appalachian, Permian, and Williston Basins.

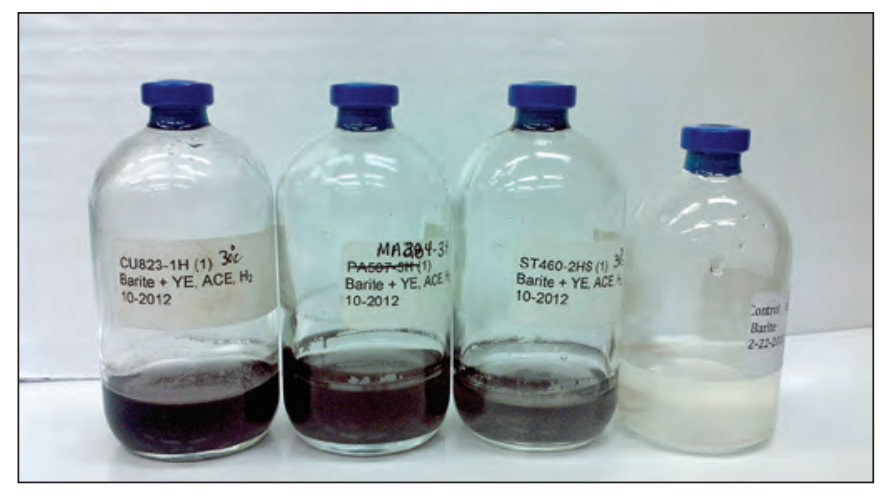

Cultures of hydrogen sulfide-producing bacteria enriched from shale gas-produced waters. The black color denotes the presence of insoluble iron sulfide minerals, an indicator of bacterial sulfide production. The clear culture on the right is an uninoculated control sample. Photograph by Darren Dunlap, USGS.

Scientists have also begun studying microorganisms in produced water, from both environmental and resource perspectives. For example, the presence of hydrogen sulfide-producing bacteria could negatively impact the success of gas extraction; souring of wells and the corrosion of drilling equipment are two well-known problems caused by hydrogen sulfide produced in the reservoir or well bore by bacteria as a byproduct of their metabolic processes. On the other hand, microorganisms could be used to enhance natural gas production or to mitigate potential contaminants. In recent investigations, USGS scientists studied microbial populations in produced water from shale gas production in northern Pennsylvania. Additional efforts to characterize microorganisms in produced water are being carried out in unison with sampling efforts to characterize chemical and physical properties.

\section{Research Activities Inform Management Decisions}

An example of USGS and industry collaboration includes investigating the results of beneficial uses for produced water from coalbed methane wells in the Powder River Basin of Wyoming
Table 1. Chemical data for selected constituents from three produced water samples in the National Produced Waters Geochemical Database. Data reported in units of milligrams per liter of fluid.

[National Produced Waters Geochemical Database, http://energy.usgs.gov/ EnvironmentalAspects/EnvironmentalAspectsofEnergyProductionandUse/ ProducedWaters.aspx\#3822349-data]

\begin{tabular}{lrcc}
\hline Constituent & $\begin{array}{c}\text { Conventional } \\
\text { oil well } \\
\text { in Ohio }\end{array}$ & $\begin{array}{c}\text { Coalbed } \\
\text { methane well } \\
\text { in Wyoming }\end{array}$ & $\begin{array}{c}\text { Shale gas } \\
\text { well in } \\
\text { Pennsylvania }\end{array}$ \\
\hline $\begin{array}{l}\text { Total dissolved } \\
\text { solids }\end{array}$ & 472,000 & 1,020 & 186,000 \\
Barium & Not reported & 19.5 & 13,600 \\
\hline Bicarbonate & Not reported & 487 & 57.1 \\
Bromide & 1,580 & 38.9 & 872 \\
Calcium & 42,800 & 337 & 11,200 \\
Chloride & 292,000 & 12.0 & 98,300 \\
Iodide & 17.9 & Not reported & Not reported \\
Magnesium & 8,350 & 10.0 & 858 \\
Sodium & 122,000 & 110 & 39,100 \\
Strontium & 736 & 9.7 & 3,580 \\
Sulfate & Not reported & Below & 50.0 \\
\hline
\end{tabular}

and Montana. The produced water in the basin generally is of relatively low salinity, but it contains high levels of sodium, which poses a possible threat to soil quality. USGS scientists, working in conjunction with the U.S. Department of Energy's National Energy Technology Laboratory and an industry collaborator, examined the potential impacts of using such water in a subsurface drip irrigation system. In this system, treated coalbed-methane water was injected about 3 feet below the ground surface to support the growth of forage crops (Engle and others, 2011; Bern and others, 2013; Sams and others, 2014). Using geophysical and geochemical techniques, the water and solutes in the system were tracked. Results from this investigation suggest that calcium release from the continued dissolution of the nearly ubiquitous mineral gypsum $\left(\mathrm{CaSO}_{4} \cdot 2 \mathrm{H}_{2} \mathrm{O}\right)$ inhibits sodium accumulation from reaching deleterious levels in soil. Findings from this work are helping operators understand the need to track gypsum content in soil to better manage subsurface drip irrigation systems that utilize coalbed methane-produced water.

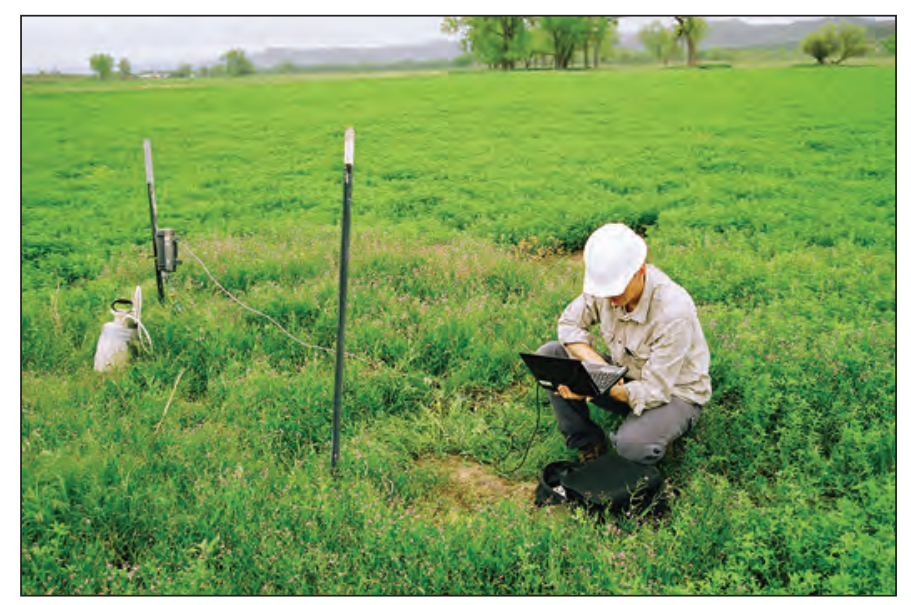

USGS employee downloading soil moisture data at a subsurface drip irrigation site utilizing coalbed methane-produced water to grow the surrounding alfalfa, Johnson County, Wyoming. Photograph by Bruce Engle, USGS volunteer. 
In oil- and gas-bearing States of the northern and northeastern United States (such as Michigan, Ohio, Pennsylvania, and New York), spreading relatively saline produced waters on roads has been a method used for decades to provide dust suppression on dirt roads during warmer months and deicing of paved roads during the winter. Although the most concentrated solutes in produced waters from this region (that is, sodium, calcium, and chloride) are relatively benign, there is a possibility that trace constituents can accumulate in areas of road spreading. For example, characterization studies by Rowan and others (2011) show that the radium content of produced water from Pennsylvania and New York is geologically anomalous. Radium derived from the decay of uranium and thorium in the reservoir rocks is a radioactive element found in many produced waters. Because radium has an affinity for fine sediments, such as clays, USGS scientists have begun collecting soil samples adjacent to areas of road spreading to determine if such an accumulation is occurring. Initial results have yielded limited evidence for radium accumulation in areas of road spreading (Skalak and others, 2014). Such information is provided to the public to help allow for informed decisions pertaining to this beneficial use.

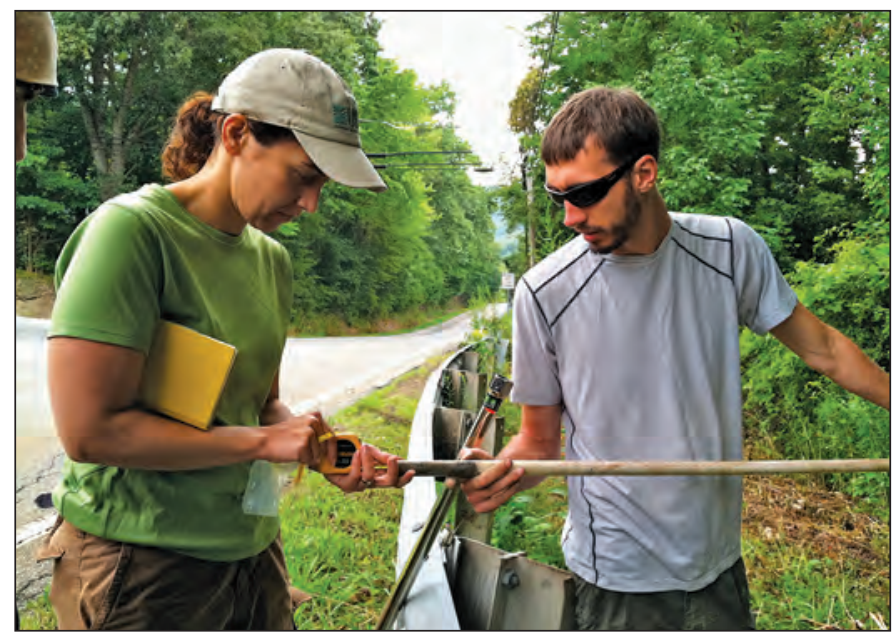

USGS scientists inspect a sediment core collected adjacent to an area of produced water road spreading, Crawford County, Pennsylvania. Photograph by Mark Engle, USGS.

\section{Outreach, Collaboration, and Future Directions}

As changes occur in how petroleum resources are exploited or how produced water is used and disposed of, the USGS continues to track and modify research objectives and directions. For example, as production from shale-gas and tight-oil reservoirs have increased, the USGS has shifted its research to focus on produced water from those sources. To learn more about current and future research directions, as well as links to publications, data, and resources, visit these Web sites: Energy Resources Program-Produced Waters (http://energy.usgs. gov/HealthEnvironment/EnergyProductionUse/ProducedWaters.aspx) and Environmental Health - Toxic Substances (http://toxics.usgs.gov/ highlights/ph20.html).

The research activities described in this fact sheet are conducted in collaboration with other USGS projects, including the "Brine Contamination to Prairie Potholes from Energy Development in the Williston Basin" project (http://steppe.cr.usgs.gov/); with other Federal agencies such as the Bureau of Reclamation and the U.S. Department of Energy; with State agencies, including water and oil and gas agencies; and with industry groups and hydrocarbon producers.

\section{References Cited}

Bern, C.R., Boehlke, A.R., Engle, M.A., Geboy, N.J., Schroeder, K.T., Zupancic, J.W., 2013, Shallow groundwater and soil chemistry response to 3 years of subsurface drip irrigation using coalbedmethane-produced water: Hydrogeology Journal, v. 21, p. 1803-1820, http://dx.doi.org/10.1007/s10040-013-1058-0.

Blondes, M.S., Gans, K.D., Thordsen, J.J., Reidy, M.E., Thomas, Burt, Engle, M.A., Kharaka, Y.K., and Rowan, E.L., 2014, U.S. Geological Survey national produced waters geochemical database v2.0 (provisional): U.S. Geological Survey Web page accessed September 22, 2014, at http://energy.usgs.gov/EnvironmentalAspects/EnvironmentalAspectsof EnergyProductionandUse/ProducedWaters.aspx\#3822349-data.

Clark, C.E, and Veil, J.A., 2009, Produced water volumes and management practices in the United States: Argonne National Laboratory Report ANL/EVS/R-09/1, 60 p.

Engle, M.A., Bern, C.R., Healy, R.W., Sams, J.I., Zupancic, J.W., and Schroeder, K.T., 2011, Tracking solutes and water from subsurface drip irrigation application of coalbed methane-produced waters, Powder River Basin, Wyoming: Environmental Geosciences, v. 18, p. 169-187, http://dx.doi.org/10.1306/eg.03031111004.

Engle, M.A., and Rowan, E.L., 2014, Geochemical evolution of produced waters from hydraulic fracturing of the Marcellus Shale, northern Appalachian Basin-A multivariate compositional data analysis approach: International Journal of Coal Geology, v. 126, p. 45-56, http://dx.doi.org/10.1016/j.coal.2013.11.010.

Herkelrath, W.N., Kharaka, Y.K., Thordsen, J.J., and Abbott, M.M., 2007, Hydrology and subsurface transport of oil-field brine at the U.S. Geological Survey OSPER site "A", Osage County, Oklahoma: Applied Geochemistry, v. 22, no. 10, p. 2155-2163, http://dx.doi.org/10.1016/j.apgeochem.2007.04.004.

Kharaka, Y.K., Kakouros, Evangelos, Thordsen, J.J., Ambats, Gil, and Abbott, M.M., 2007, Fate and groundwater impacts of produced water releases at OSPER "B" site, Osage County, Oklahoma: Applied Geochemistry, v. 22, no. 10, p. 2164-2176, http://dx.doi.org/10.1016/j.apgeochem.2007.04.005.

Pennsylvania Department of Environmental Protection, 2013, Oil and gas reporting Web site, accessed June 27, 2013, at https://www.paoilandgasreporting.state.pa.us/publicreports/ Modules/Welcome/Welcome.aspx.

Polyak, D.E., 2013, Iodine: U.S. Geological Survey Minerals Yearbook 2012, 6 p., accessed September 22, 2014, from http://minerals.usgs.gov/ minerals/pubs/commodity/iodine/index.html.

Rowan, E.L., Engle, M.A., Kirby, C.S., and Kraemer, T.F., 2011, Radium content of oil- and gas-field produced waters in the northern Appalachian Basin (USA) - Summary and discussion of data: U.S. Geological Survey Scientific Investigations Report 2011-5135, 31 p., http://pubs.usgs.gov/sir/2011/5135/.

Sams, J.I., Veloski, Garret, Smith, B.D., Minsley, B.J., Engle, M.A., Lipinski, B.A., Hammack, Richard, and Zupanicic, J.W., 2014, Application of near-surface geophysics as part of a hydrologic study of a subsurface drip irrigation system along the Powder River floodplain near Arvada, Wyoming: International Journal of Coal Geology, v. 126, p. 128-139, http://www.sciencedirect.com/science/article/pii/ S0166516213002413.

Skalak, K.J., Engle, M.A., Rowan, E.L., Jolly, G.D., Conko, K.M., Benthem, A.J., and Kraemer, T.F., 2014, Surface disposal of produced waters in western and southwestern Pennsylvania-Potential for accumulation of alkali-earth elements in sediments: International Journal of Coal Geology, v. 126, p. 162-170, http://www.sciencedirect.com/ science/article/pii/S0166516213002681.

Thamke, J.N., and Smith, B.D., 2014, Delineation of brine contamination in and near the East Poplar oil field, Fort Peck Indian Reservation, northeastern Montana, 2004-09: U.S. Geological Survey Scientific Investigations Report 2014-5024, 40 p., http://dx.doi.org/10.3133/ sir20145024. 